\title{
David LloYD, Beckett's Thing. Painting and Theatre. Edinburgh University Press, 2016
}

\section{Alexandra Poulain}

\section{(2) OpenEdition}

1 Journals

\section{Electronic version}

URL: http://journals.openedition.org/etudesirlandaises/5388

DOI: 10.4000/etudesirlandaises.5388

ISSN: 2259-8863

\section{Publisher}

Presses universitaires de Caen

\section{Printed version}

Date of publication: 29 November 2017

Number of pages: $153-154$

ISBN: 978-2-7535-7388-8

ISSN: 0183-973X

\section{Electronic reference}

Alexandra Poulain, « David LLoyd, Beckett's Thing. Painting and Theatre. Edinburgh University Press, 2016 », Études irlandaises [Online], 42-2 | 2017, Online since 29 November 2017, connection on 24 September 2020. URL : http://journals.openedition.org/etudesirlandaises/5388 ; DOI : https://doi.org/ 10.4000/etudesirlandaises.5388

\section{(c) (†) 8 ()}

Études irlandaises est mise à disposition selon les termes de la Licence Creative Commons Attribution - Pas d'Utilisation Commerciale - Partage dans les Mêmes Conditions 4.0 International. 


\title{
Comptes rendus de lecture
}

\author{
Book Reviews
}

David Lloyd, Beckett's Thing. Painting and Theatre. Edinburgh University Press, 2016, 272 p., ISBN 978474415729 (hardback), ISBN 978474415736 (webready PDF), ISBN 978474415743 (epub), £75.00.

As David Lloyd reminds us in the introduction of his new book, Beckett's Thing. Painting and Theatre, Beckett was a lover of the visual arts throughout his life. He could spend hours in museums and galleries gazing at individual paintings, practising a certain quality of attention to the composition and materiality of the works, evident in his critical writings on the painting. He was also very well acquainted with Western art history and in theories of modern painting, and it has often been argued that his own writing, especially where it involved a visual dimension, was influenced by specific paintings. This is acknowledged in this book, but tracing influences (a speculative venture except - or perhaps especially - in those rare cases when Beckett himself acknowledged specific influences, as when he claimed that Not $I$ had been inspired by his memory of Caravaggio's "The Beheading of John the Baptist") is not what this book is about. Rather it focuses on three painters whom Beckett not only admired but with whom he became friends, saw on a regular basis and with whom he exchanged views on their respective arts (in letters or on long, mainly silent walks): Jack B. Yeats, whom Beckett knew as a young man in Dublin, Bram van Velde whom he befriended in post-war Paris and who features prominently in the "Three Dialogues with Georges Duthuit", and Avigdor Arikha, the young Jewish-Romanian painter whom he befriended in Paris and with whom he remained friends until his death in 1989. The three chapters in the book are devoted respectively to Beckett's relationship with each of the three painters. Reading Beckett's writings on these artists very closely, and paying particular attention to the paintings themselves, Lloyd attempts to reconstruct Beckett's gaze, and to see what it was that Beckett saw in them that opened ways for his own aesthetic search. Thus he shows persuasively how these painters' experimentations with form and matter translate, 
at three distinct periods in Beckett's life, into his visual aesthetic as implemented in his works for theatre, television and film.

The central thesis of the book is that the three painters which Beckett knew most intimately form "a constellation of minor painting" which "challenges the dominant givens of a canonical tradition" (12) and relentlessly looks for alternatives to the relations of domination and possession inherent in the regime of representation. Thus, Lloyd argues, Beckett's engagement with the works of Jack B. Yeats, Bram van Velde and Avigdor Arikha pointed him out of the impasse of "the subject-object relation", towards a visual aesthetic that desists from the ethical and political tenets of the Western tradition of representation. The eponymous "thing" which Beckett relentlessly sought to express (not capture!) is what remains of the human after the cataclysms which have left "humanity in ruins" in the post-war era: neither subject nor object, but a "human thing" suspended among its things that resists total annihilation. As he does elsewhere in his oeuvre, Lloyd weaves together the aesthetic, ethical and political strands of artistic work, lucidly teasing out the various implications of the process of representation - and convincingly showing the congruence between the aesthetic and political senses of the term. In the process, he offers a decisive contribution to recent reappraisals of Beckett as a profoundly political writer.

While the book offers a tantalizingly new way of thinking about Beckett's visual imagination and of understanding his work with theatre, television and film, it also provides a fascinating account of the debates raised by formal experimentations in Western post-war painting. More importantly, perhaps, it also provides superb reproductions of over sixty works by Yeats, Van Velde, Arikha and many others, and invents a kind of ethical ekphrasis which seeks to give an account of the paintings (with special emphasis on their materiality, on the quality and degree of exposure of the canvass, or the thickness of the impasto) without "reading" them, and thus reducing them to objects of the commentator's subjective, interpretive gaze. Finally, in tracing Beckett's dogged pursuit of an art form that would not somehow imply a form of domination, David Lloyd's new book makes a compelling argument for the value of human thingness.

Alexandra Poulain

Michael McAteer, ed., Silence in Modern Irish Literature, Leiden, Brill, 2017, vII-217 p., ISBN 978-90-04-34273-6, €116,00.

Staining the Silence... Celebrating the virtues of silence over literary expression, Samuel Beckett famously remarked, "Every work is like an unnecessary stain 